\title{
Milk fatty acid profile of Holstein x Gyr cows on 'Marandu' grass pasture under different grazing strategies
}

\author{
Bárbara Cardoso da Mata e Silva( ${ }^{(1)}$, Norberto Mario Rodriguez ${ }^{(2)}$, Mirton José Frota Morenz ${ }^{(3)}$, Marco Antônio \\ Sundfeld da Gama ${ }^{(3)}$, Carlos Eugênio Martins ${ }^{(3)}$, Domingos Sávio Campos Paciullo(3), Carlos Augusto de \\ Miranda Gomide( ${ }^{(3)}$, Albert José dos Anjos ${ }^{(4)}$, Afrânio Silva Madeiro( ${ }^{(5)}$ and Fernando César Ferraz Lopes ${ }^{(3)}$
}

\begin{abstract}
(1)Universidade José do Rosário Vellano, Programa de Pós-Graduação em Reprodução, Sanidade e Bem-Estar Animal, Rodovia MG-179, Km 0, Trevo, CEP 37130-000 Alfenas, MG, Brazil. E-mail: barbaracmsilva@yahoo.com.br (2)Universidade Federal de Minas Gerais, Departamento de Zootecnia, Avenida Antônio Carlos, no6.627, CEP31270-901 BeloHorizonte, MG, Brazil. E-mail:norberto.bhe@terra.com.br ${ }^{(3)}$ Embrapa Gado de Leite, Rua Eugênio do Nascimento, no 610, Dom Bosco, CEP 36038-330 Juiz de Fora, MG, Brazil. E-mail: mirton.morenz@embrapa.br, marco.gama@embrapa.br, carlos.eugenio@embrapa.br, domingos.paciullo@embrapa.br, carlos.gomide@embrapa.br, fernando.lopes@embrapa.br (4)Universidade Federal dos Vales do Jequitinhonha e Mucuri, Programa de PósGraduação em Zootecnia, Rodovia MG-367, Km 583, no 5.000, CEP 39100-000 Diamantina, MG, Brazil. E-mail: albert@zootecnista.com.br ${ }^{(5)}$ Escola Agrotécnica da Universidade Federal de Roraima, Campus Murupu, Rodovia 174, Km 37, s/no, CEP $69300-000$ Boa Vista, RR, Brazil. E-mail: afraniomadeiro@hotmail.com
\end{abstract}

\begin{abstract}
The objective of this work was to evaluate the milk fatty acid (FA) profile of Holstein x Gyr cows subjected to two different grazing managements (fixed and variable rest periods) of Urochloa brizantha 'Marandu' pastures. A randomized complete block design was used, with two replicates of pasture areas (blocks) per treatment and four cows per block. Milk production and composition were not affected by grazing strategies. No treatment effects were observed on the proportions ( $\mathrm{g} 100 \mathrm{~g} \mathrm{~g}^{-1}$ of total FA) of the main FAs (palmitic, linoleic, and $\alpha$-linolenic) of the pasture, but their intakes (grams per day) were affected by differences in forage dry matter intake. The concentrations of FAs in milk plasma and fat were not affected by the treatments. Milk fat contents of rumenic, vaccenic, oleic, and $\alpha$-linolenic acids varied from 0.71 to 0.93 ,

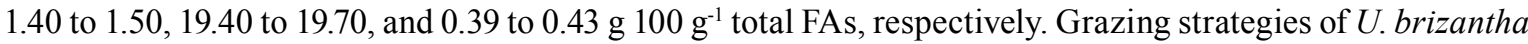
'Marandu' cause no changes on the milk fatty acid profile of cows.
\end{abstract}

Index terms: Urochloa brizantha, conjugated linoleic acid, rumenic acid, tropical grass.

\section{Perfil de ácidos graxos do leite de vacas Holandesas x Gir em diferentes manejos de pastagem de capim-marandu}

\begin{abstract}
Resumo - O objetivo deste trabalho foi avaliar o perfil de ácidos graxos (AG) do leite de vacas Holandesas x Gir submetidos a dois tipos de manejo de pastejo (períodos de descanso fixo e variável) de pastagem de Urochloa brizantha 'Marandu'. Utilizou-se o delineamento de blocos ao acaso, com duas repetições de área de pastagem (blocos) por tratamento e quatro vacas por bloco. A produção e a composição do leite não foram

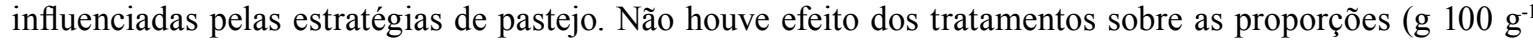
de AG totais) dos principais AG (palmítico, linoleico e $\alpha$-linolênico) do pasto, mas suas ingestões (gramas por dia) foram influenciadas pelas diferenças de ingestão de matéria seca da forragem. As concentrações dos AG no plasma e na gordura do leite não foram influenciadas pelos tratamentos. As concentrações dos ácidos rumênico, vacênico, oleico e $\alpha$-linolênico na gordura do leite variaram de 0,71 a $0,93,1,40$ a 1,50, 19,40 a 19,70

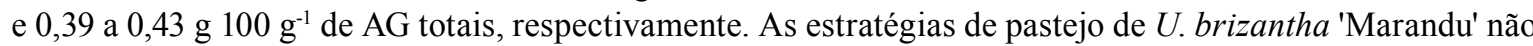
alteram o perfil de ácidos graxos do leite das vacas.
\end{abstract}

Termos para indexação: Urochloa brizantha, ácido linoleico conjugado, ácido rumênico, gramínea tropical.

\section{Introduction}

Research indicates that biologically active compounds, naturally present in milk fat, have positive effects on human health, particularly rumenic acid (cis-9, trans-11 CLA), with anticarcinogenic, antidiabetogenic (type 2 diabetes), antiatherogenic, and immunomodulatory properties, and vaccenic acid (trans-11 C18:1), responsible for 64 to $97 \%$ of the total secretion of rumenic acid in bovine milk (Shingfield et al., 2008). Also noteworthy is oleic acid (cis-9 C18:1), which is associated with the reduction of the LDL fraction of cholesterol, and $\alpha$-linolenic acid (cis-9, cis-12, cis-15 C18:3), essential for human metabolism 
and a precursor of other $\omega-3$ fatty acids (FA), which are considered to have cardioprotective and antiinflammatory properties (Fats..., 2010).

The main strategy to obtain milk containing fat naturally enriched with rumenic and vaccenic acids is to provide diets with ingredients rich in linoleic (cis9, cis-12 C18:2) and $\alpha$-linolenic FAs. Milk production systems based on pastures with tropical grasses, which have high levels of these two polyunsaturated FAs, are promising models for the production of milk with an FA profile that is more beneficial to human health, in other words, with higher concentrations of rumenic, vaccenic, and oleic FAs, and lower levels of lauric (C12:0), myristic (C14:0) and palmitic (C16:0) saturated FAs (Lopes et al., 2015), which are considered hypercholesterolemic (Fats..., 2010).

Numerous factors are involved in the modulation of the FA profiles of forages, such as plant species and cultivar, age of forage growth, season of the year, forage conservation method (for instance, hay, silage), and the level of nitrogen fertilization (Lopes et al., 2015). Aspects related to pasture management have also the potential to promote changes in the contents of polyunsaturated FAs in pastures and, therefore, in the FA profile of cows' milk (Bargo et al., 2006; Palladino et al., 2009, 2014). In Brazil, systems of rotational grazing under intermittent stocking, based on the use of fixed or variable pasture rest periods, have been studied. In pastures of $U$. brizantha 'Marandu', Madeiro (2014) and Anjos et al. (2016) compared the morphological and chemical compositions of pastures managed under fixed 30-day rest periods with variable rest periods, based on the interception of $95 \%$ of the photosynthetically active radiation. These authors observed a greater leaf proportion, a lower proportion of senescent material and, therefore, a higher nutritional value in pastures managed under variable rest periods. However, we did not find studies in the literature evaluating the effect of these two pasture management strategies on the FA profile of cow's milk.

In addition to the novelty of the present study, for the advancement of scientific knowledge in the area, it should be emphasized that the studied forage accounts for approximately $50 \%$ of the pastures grown in Brazil (Macedo, 2006). Similarly, by working with the Holstein x Gyr cattle breed, used in the present study, we privileged the genetic grouping that is responsible for $80 \%$ of the milk produced in the country (Silva et al., 2015).

The objective of this work was to evaluate the milk fatty acid profile of Holstein x Gyr cows subjected to two different grazing managements (fixed and variable rest periods) on Urochloa brizantha 'Marandu' pastures.

\section{Materials and Methods}

The study was conducted at a facility of Embrapa Gado de Leite, in Coronel Pacheco, MG, Brazil, from January 25, 2012, to May 04, 2012. Sixteen multiparous Holstein x Gyr cows were used, with $93 \pm 13$ days of lactation and a yield of $14.6 \pm 2.8 \mathrm{~kg}$ per day of milk, managed under rotational grazing in 4 ha of 'Marandu' palisade grass pasture ( $U$. brizantha 'Marandu'). The evaluated pasture management treatments comprised two rest periods: variable and fixed. For the variable rest period, cows entered the paddocks whenever the pasture reached 95\% canopy-light interception - estimated by a canopy analyzer AccuPAR Linear PAR/LAI Ceptometer, model LP-80 (Decagon Devices Inc., Pullman, WA, USA); for the fixed rest period, the pasture was managed to allow 30 days of rest. It should be noted that this experimental area had previously been managed using these treatments since October 2010 (Anjos et al., 2016).

A randomized complete block design was used, with two replicates of pasture area per treatment and, in each replicate, four cows were evenly distributed based on the blood percentage in crossbreding, milk yield, body weight, and lactation order. All cows received $2.8 \mathrm{~kg}$ per day of concentrate (as-fed basis), with $88.8 \%$ dry matter (DM), $20.5 \%$ crude protein (CP), 11.4\% neutral detergent fibre (NDF), 4.0\% acid detergent fibre, and $4.3 \%$ ether extract (EE), offered in portions in conjunction with the two daily milkings (5:00 a.m. and 3:00 p.m.). The concentrate comprised,

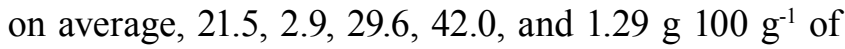
total FAs, of palmitic, stearic (C18:0), oleic, linoleic and $\alpha$-linolenic FAs, respectively. In both treatments, the stocking period of pastures was three days, with a goal of 20-25 cm post-grazing heights, and stocking rate was adjusted by the put-and-take technique, using nonlactating cows. Forage supply was never less than $5.5 \mathrm{~kg}$ dry matter mass per $100 \mathrm{~kg}$ body weight. Pasture 
fertilization was conducted after cows were removed, with $50 \mathrm{~kg} \mathrm{ha}^{-1} \mathrm{~N}$ and $\mathrm{K}_{2} \mathrm{O}$, and $12.5 \mathrm{~kg} \mathrm{ha}^{-1} \mathrm{P}_{2} \mathrm{O}_{5}$.

Three periods (grazing cycles) of plasma and milk samplings occurred in addition to estimates of individual pasture consumption. After recording the daily production, milk samples were collected, transferred to bottles without preservatives, and stored at $-10^{\circ} \mathrm{C}$ for future determination of FA profile at the laboratory of chromatography of Embrapa Gado de Leite. This FA profile was performed according to description by Ribeiro et al. (2014), in a $6890 \mathrm{~N}$ gas-phase chromatograph (Agilent Technologies Inc., Santa Clara, CA, USA) equipped with a CP-Sil 88 for FAME $100 \mathrm{~m} \times 0.25 \mathrm{~mm} \times 0.2 \mu \mathrm{m}$ (Agilent Technologies Inc., Santa Clara, CA, USA) column and flame ionization detector. In another flask containing the preservative bronopol, milk samples were collected concomitantly for analysis of centesimal composition and for the content of milk urea nitrogen (MUN). Analyses were conducted at the laboratory of milk quality of Embrapa Gado de Leite.

To evaluate the nutritional quality of milk fat, equations were used to calculate the atherogenicity index(AI), thrombogenicityindex(TI), omega 6: omega 3 FA ratio ( $\omega-6: \omega-3)$, and hypo/hypercholesterolemic FA ratio $(\mathrm{h} / \mathrm{H})$ (Ribeiro et al., 2014), as follows:

$\mathrm{AI}=[\mathrm{C} 12: 0+(4 \times \mathrm{C} 14: 0)+\mathrm{C} 16: 0] /($ cis $-9 \mathrm{C} 18: 1+\Sigma$ cis $\omega-6 \mathrm{FA}+\Sigma$ cis $\omega-3 \mathrm{FA})$;

$\mathrm{TI}=(\mathrm{C} 14: 0+\mathrm{C} 16: 0+\mathrm{C} 18: 0) /[(0.5 \times$ cis $-9 \mathrm{C} 18: 1)+$ $(0.5 \times \Sigma$ cis $\omega-6 \mathrm{FA})+(3 \times \Sigma$ cis $\omega-3 \mathrm{FA})+(\Sigma$ cis $\omega-3$ FA / $\Sigma$ cis $\omega-6$ FA)];

$\omega-6: \omega-3 \mathrm{FA}=\Sigma$ cis $\omega-6 \mathrm{FA} / \Sigma$ cis $\omega-3 \mathrm{FA}$; and

$\mathrm{h} / \mathrm{H} \mathrm{FA}=($ cis-9 $\mathrm{C} 18: 1+\Sigma$ cis $\omega-3 \mathrm{FA}) /(\mathrm{C} 12: 0+$ C14:0 + C16:0), in which

$\Sigma$ cis $\omega-3$ FA $=$ cis-6, cis- 9 , cis-15 $\alpha-\mathrm{C} 18: 3+\mathrm{C} 20: 5$ $\omega-3$ EPA + C22:5 $\omega-3$ DPA; and

$\Sigma$ cis $\omega-6$ FA $=$ cis-9, cis-12 C18:2 + cis-6, cis-9, cis$12 \gamma-\mathrm{C} 18: 3+$ cis-11, cis-14 C20:2 + cis-8, cis-11, cis-14 C20:3 + cis-5, cis-8, cis-11, cis-14 C20:4

The daily consumption of pasture DM was estimated using the external indicator LIPE ( 0.5 gram per cow per day), provided after the morning milking. Periods of two and six days were observed for adaptation to the indicator and for faeces collection, respectively. On the last day of faecal sampling, blood was collected by puncture of the coccygeal vein in vacuum tubes containing EDTA- $\mathrm{K}_{3}$. The tubes were then centrifuged $(1,122 \times g ; 15 \mathrm{~min})$ for plasma separation, for FA profile analysis by gas chromatography (Masood et al., 2005), and for determination of the concentrations of glucose, plasma-urea nitrogen (PUN) and nonesterified FAs (NEFA) using enzymatic kits, as described by Ribeiro et al. (2014).

During the week of faecal collections, on the day before the cows entered the grazing paddocks, forage samples were collected by simulated grazing to $25 \mathrm{~cm}$ post-grazing heights. A half of the samples was stored $\left(-10^{\circ} \mathrm{C}\right)$, then it was pre-dried, ground $(1 \mathrm{~mm})$, and analysed for chemical composition, according to procedures reported by Silva \& Queiroz (2002). The other half was lyophilized and analysed for FA profile in a gas-phase chromatograph equipped with a polyethylene glycol capillary column $(25 \mathrm{~m}$ x $0.20 \mathrm{~m} \mathrm{x}$ $0.33 \mu \mathrm{m}$ ) HP-FFAP (Agilent Technologies Inc., Santa Clara, CA, USA), according to description by Ribeiro et al. (2014).

The variables were analysed as repeated measures over time, using the Mixed procedure of SAS, version 9.0 (SAS Institute, Inc., Cary, NC, USA). Treatments (Trt), grazing cycles (GC), blocks, and the interaction Trt x GC were considered as fixed effects, whereas blocks and their interactions were considered as random effects. When the Trt x GC interaction was considered significant, the SLICE option of LSMEANS of SAS was used. Pearson's correlation coefficients were obtained by the CORR procedure of SAS. Effects were considered significant when $\mathrm{p} \leq 0.05$.

\section{Results and Discussion}

The Trt $x$ GC interaction was observed for the plasma concentrations of NEFA, glucose and PUN (Table 1). However, the treatments had no effect on the levels of these metabolites in plasma. The value ranges obtained for plasma concentrations of NEFA and glucose were within the normally observed values for lactating cows (Cunningham, 2004). The grazing cycle affected the levels of PUN, which were generally elevated (Table 1), considering the ideal range of 12 to $14 \mathrm{mg} \mathrm{dL}^{-1}$ recommended by Rajala-Schultz \& Saville (2003). In the pasture managed by variable rest periods, the higher PUN content, observed in the third grazing cycle (Table 1), can be justified by the higher CP content (16.9\%) in the pasture (Table 2), which resulted in higher consumption of this nutrient by cows, that is, $2.64 \mathrm{~kg}$ per cow per day (Table 3 ). In addition, in this 
treatment and grazing cycle, the highest concentration of MUN (22.0 $\mathrm{mg} \mathrm{dL}^{-1}$ ) (Table 4) was obtained. A high correlation was observed between the levels of PUN and MUN ( $\mathrm{r}=0.86, \mathrm{p}<0.0001, \mathrm{n}=48)$, corroborating that obtained by Roseler et al. (1993).

The treatment and grazing cycle, and the interaction between both affected DM, CP, EE, and NDF consumption from the pasture (Table 3). For pasture DM intake, expressed in kilogram per cow per day and percentage of body weight ( $\%$ BW), there was a difference between treatments only in the third cycle, with higher values obtained for the variable rest period, in comparison to the fixed one. The estimated consumption of $3.04 \%$ BW (Table 3 ) was the highest one in the present study, and can be considered high, when compared with the 2.4 and $2.9 \%$ BW obtained by Porto et al. (2009) and Fukumoto et al. (2010), in lactating Holstein x Gyr cows receiving 2 kg per day

Table 1. Effect of rest period and grazing cycle on the concentrations of plasma metabolites in Holstein $\mathrm{x}$ Gyr cows grazing Urochloa brizantha 'Marandu'(1).

\begin{tabular}{|c|c|c|c|c|c|}
\hline \multirow[t]{2}{*}{ Plasma metabolite ${ }^{(2)}$} & \multirow[t]{2}{*}{ Rest period } & \multicolumn{3}{|c|}{ Grazing cycle } & \multirow[t]{2}{*}{ SEM } \\
\hline & & 1 & 2 & 3 & \\
\hline \multirow{2}{*}{ Nonesterified fatty acids $\left(\mathrm{mmol} \mathrm{L}^{-1}\right)$} & Fixed & $0.248 \mathrm{Aa}$ & $0.136 \mathrm{Ab}$ & $0.073 \mathrm{Ab}$ & \multirow{2}{*}{0.0348} \\
\hline & Variable & $0.131 \mathrm{Aa}$ & $0.106 \mathrm{Aa}$ & $0.112 \mathrm{Aa}$ & \\
\hline \multirow{2}{*}{ Glucose $\left(\mathrm{mg} \mathrm{dL}^{-1}\right)$} & Fixed & $62.3 \mathrm{Aa}$ & $61.3 \mathrm{Aa}$ & $62.6 \mathrm{Aa}$ & \multirow{2}{*}{1.4999} \\
\hline & Variable & $63.6 \mathrm{Aab}$ & 65.0Aa & $60.7 \mathrm{Ab}$ & \\
\hline \multirow{2}{*}{ Nitrogen urea $\left(\mathrm{mg} \mathrm{dL}^{-1}\right)$} & Fixed & $16.2 \mathrm{Ab}$ & $17.5 \mathrm{Aab}$ & $19.0 \mathrm{Aa}$ & \multirow{2}{*}{1.0142} \\
\hline & Variable & $15.8 \mathrm{Ab}$ & $17.3 \mathrm{Ab}$ & 21.7Aa & \\
\hline
\end{tabular}

${ }^{(1)}$ Means followed by equal letters, uppercase in the columns and lowercase in the rows, do not differ at $5 \%$ probability by the LSMeans test of SAS software (SAS Institute, Inc., Cary, NC, USA). ${ }^{(2)}$ Treatment $x$ grazing cycle interaction was significant at $5 \%$ probability. SEM, standard error of the mean.

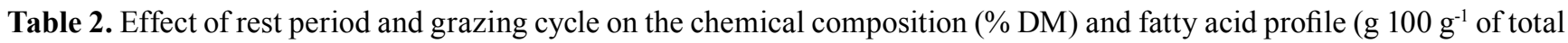
fatty acids) of Urochloa brizantha 'Marandu'(1).

\begin{tabular}{|c|c|c|c|c|c|}
\hline \multirow{2}{*}{ Chemical composition ${ }^{(2)}$} & \multirow{2}{*}{ Rest period } & \multicolumn{3}{|c|}{ Grazing cycle } & \multirow{2}{*}{ SEM } \\
\hline & & 1 & 2 & 3 & \\
\hline \multirow{2}{*}{ Crude protein } & Fixed & $13.8 \mathrm{Ab}$ & $15.2 \mathrm{Aa}$ & 14.6Bab & \multirow{2}{*}{0.2979} \\
\hline & Variable & $14.9 \mathrm{Ab}$ & $14.1 \mathrm{Ab}$ & $16.9 \mathrm{Aa}$ & \\
\hline \multirow{2}{*}{ Ether extract } & Fixed & $3.2 \mathrm{Aa}$ & $3.6 \mathrm{Aa}$ & $3.5 \mathrm{Aa}$ & \multirow{2}{*}{0.3131} \\
\hline & Variable & $3.8 \mathrm{Aa}$ & 3.7Aa & $4.0 \mathrm{Aa}$ & \\
\hline \multirow{2}{*}{ Neutral detergent fiber } & Fixed & $61.8 \mathrm{Aa}$ & $61.7 \mathrm{Aa}$ & $61.8 \mathrm{Aa}$ & \multirow{2}{*}{0.9115} \\
\hline & Variable & $64.2 \mathrm{Aa}$ & $62.8 \mathrm{Aa}$ & $60.7 \mathrm{Aa}$ & \\
\hline \multirow{2}{*}{ Lignin } & Fixed & $3.3 \mathrm{Aa}$ & $3.9 \mathrm{Aa}$ & $3.4 \mathrm{Aa}$ & \multirow{2}{*}{0.3097} \\
\hline & Variable & $3.5 \mathrm{Aa}$ & $3.4 \mathrm{Aa}$ & $3.8 \mathrm{Aa}$ & \\
\hline \multirow{2}{*}{ In vitro dry matter digestibility(\%) } & Fixed & $61.0 \mathrm{Ba}$ & 63.0Aa & $62.3 \mathrm{Bab}$ & \multirow{2}{*}{0.5127} \\
\hline & Variable & $63.1 \mathrm{Ab}$ & $61.6 \mathrm{Ab}$ & $68.4 \mathrm{Aa}$ & \\
\hline \multirow{2}{*}{$\mathrm{C} 16: 0$} & Fixed & $30.6 \mathrm{Aa}$ & $29.6 \mathrm{Aa}$ & $29.7 \mathrm{Aa}$ & \multirow{2}{*}{0.5951} \\
\hline & Variable & $29.7 \mathrm{Ab}$ & $32.5 \mathrm{Aa}$ & $27.5 \mathrm{Ac}$ & \\
\hline \multirow{2}{*}{$\mathrm{C} 18: 0$} & Fixed & $1.8 \mathrm{Aa}$ & $1.7 \mathrm{Aa}$ & $1.6 \mathrm{Aa}$ & \multirow{2}{*}{0.0475} \\
\hline & Variable & $1.7 \mathrm{Ab}$ & $2.0 \mathrm{Aa}$ & $1.5 \mathrm{Ab}$ & \\
\hline \multirow{2}{*}{ cis-9 C18:1 } & Fixed & $3.5 \mathrm{Aa}$ & $3.2 \mathrm{Aa}$ & $3.6 \mathrm{Aa}$ & \multirow{2}{*}{0.2509} \\
\hline & Variable & $3.0 \mathrm{Aa}$ & $4.2 \mathrm{Aa}$ & 3.0Aa & \\
\hline \multirow{2}{*}{ cis-9, cis-12 C18:2 } & Fixed & $21.1 \mathrm{Aa}$ & $20.5 \mathrm{Aa}$ & $21.5 \mathrm{Aa}$ & \multirow{2}{*}{0.3967} \\
\hline & Variable & $20.8 \mathrm{Aa}$ & $22.6 \mathrm{Aa}$ & $19.5 \mathrm{Aa}$ & \\
\hline \multirow{2}{*}{ cis-9, cis-12, cis-15 C18:3 } & Fixed & $35.8 \mathrm{Ab}$ & 37.3Aab & $37.9 \mathrm{Aa}$ & \multirow{2}{*}{0.5169} \\
\hline & Variable & $39.4 \mathrm{Aa}$ & $33.6 \mathrm{Ab}$ & $37.8 \mathrm{Aa}$ & \\
\hline
\end{tabular}

${ }^{(1)}$ Means followed by equal letters, uppercase in the columns and lowercase in the rows, do not differ at $5 \%$ probability by the LSMeans test. ${ }^{(2)}$ Treatment $\mathrm{x}$ grazing cycle interaction was significant at $5 \%$ probability for crude protein and in vitro dry matter digestibility. SEM, standard error of the mean. 
Table 3. Effect of rest period and grazing cycle on the estimated consumption of nutrients and fatty acids by Holstein x Gyr cows, in Urochloa brizantha 'Marandu' pasture ${ }^{(1)}$.

\begin{tabular}{|c|c|c|c|c|c|}
\hline \multirow[t]{2}{*}{ Nutrient/Fatty Acid ${ }^{(2)}$} & \multirow[t]{2}{*}{ Rest period } & \multicolumn{3}{|c|}{ Grazing cycle } & \multirow[t]{2}{*}{ SEM } \\
\hline & & 1 & 2 & 3 & \\
\hline \multirow{2}{*}{$\begin{array}{l}\text { Dry matter } \\
\text { (kg per cow per day) }\end{array}$} & Fixed & $11.6 \mathrm{Aa}$ & $10.6 \mathrm{Aa}$ & $11.4 \mathrm{Ba}$ & \multirow{2}{*}{0.1918} \\
\hline & Variable & $12.0 \mathrm{Ab}$ & $10.6 \mathrm{Ac}$ & $15.5 \mathrm{Aa}$ & \\
\hline \multirow{2}{*}{$\begin{array}{l}\text { Dry matter } \\
\text { (\% live weight) }\end{array}$} & Fixed & $2.35 \mathrm{Aa}$ & $2.12 \mathrm{Ab}$ & $2.23 \mathrm{Bab}$ & \multirow{2}{*}{0.0585} \\
\hline & Variable & $2.34 \mathrm{Ab}$ & $2.07 \mathrm{Ac}$ & $3.04 \mathrm{Aa}$ & \\
\hline \multirow{2}{*}{$\begin{array}{l}\text { Crude protein } \\
\text { (kg per cow per day) }\end{array}$} & Fixed & $1.60 \mathrm{Ba}$ & $1.60 \mathrm{Aa}$ & $1.66 \mathrm{Ba}$ & \multirow{2}{*}{0.0421} \\
\hline & Variable & $1.77 \mathrm{Ab}$ & $1.50 \mathrm{Ac}$ & $2.64 \mathrm{Aa}$ & \\
\hline \multirow{2}{*}{$\begin{array}{l}\text { Ether extract } \\
\text { (g per cow per day) }\end{array}$} & Fixed & $364.5 \mathrm{Bb}$ & 376.1Aab & $401.9 \mathrm{Ba}$ & \multirow{2}{*}{0.1521} \\
\hline & Variable & $453.6 \mathrm{Ab}$ & $390.4 \mathrm{Ac}$ & $624.3 \mathrm{Aa}$ & \\
\hline \multirow{2}{*}{$\begin{array}{l}\text { Neutral detergent fiber } \\
\text { (kg per cow per day) }\end{array}$} & Fixed & 7.17Ba & $6.52 \mathrm{Ab}$ & $7.07 \mathrm{Ba}$ & \multirow{2}{*}{0.1166} \\
\hline & Variable & $7.67 \mathrm{Ab}$ & $6.65 \mathrm{Ac}$ & $9.43 \mathrm{Aa}$ & \\
\hline \multirow{2}{*}{$\begin{array}{l}\text { cis-9 C18:1 } \\
\text { (g per cow per day) }\end{array}$} & Fixed & $7.8 \mathrm{Aa}$ & $6.2 \mathrm{Bb}$ & $8.1 \mathrm{Ba}$ & \multirow{2}{*}{0.5575} \\
\hline & Variable & $7.7 \mathrm{Ab}$ & 7.9Ab & $10.6 \mathrm{Aa}$ & \\
\hline \multirow{2}{*}{$\begin{array}{l}\text { cis-9, cis-12 C18:2 } \\
\text { (g per cow per day) }\end{array}$} & Fixed & $47.3 \mathrm{Aa}$ & $39.5 \mathrm{Ab}$ & $48.1 \mathrm{Ba}$ & \multirow{2}{*}{2.1842} \\
\hline & Variable & $52.5 \mathrm{Ab}$ & $42.7 \mathrm{Ac}$ & $68.4 \mathrm{Aa}$ & \\
\hline \multirow{2}{*}{$\begin{array}{l}\text { cis-9, cis-12, cis-15 C18:3 } \\
\text { (g per cow per day) }\end{array}$} & Fixed & $80.4 \mathrm{Ba}$ & $72.0 \mathrm{Ab}$ & $84.7 \mathrm{Ba}$ & \multirow{2}{*}{2.9320} \\
\hline & Variable & $99.2 \mathrm{Ab}$ & $63.8 \mathrm{Bc}$ & $132.9 \mathrm{Aa}$ & \\
\hline
\end{tabular}

${ }^{(1)}$ Means followed by equal letters, uppercase in the columns and lowercase in the rows, do not differ at $5 \%$ probability by the LSMeans test. ${ }^{(2)}$ Treatment $x$ grazing cycle interaction was significant at $5 \%$ probability. SEM, standard error of the mean.

Table 4. Effect of the rest period and grazing cycle on the production and composition of milk from Holstein $\mathrm{x}$ Gyr cows in an Urochloa brizantha 'Marandu' pasture ${ }^{(1)}$.

\begin{tabular}{|c|c|c|c|c|c|}
\hline \multirow[t]{2}{*}{ Variable } & \multirow[t]{2}{*}{ Rest period } & \multicolumn{3}{|c|}{ Grazing cycle } & \multirow[t]{2}{*}{ SEM } \\
\hline & & 1 & 2 & 3 & \\
\hline & \multicolumn{5}{|c|}{ Milk composition } \\
\hline \multirow{2}{*}{$\begin{array}{l}\text { Fat } \\
(\%)\end{array}$} & Fixed & $3.80 \mathrm{Aa}$ & 3.79Aa & $3.86 \mathrm{Aa}$ & \multirow{2}{*}{0.2150} \\
\hline & Variable & $3.57 \mathrm{Ab}$ & $4.01 \mathrm{Ab}$ & $4.30 \mathrm{Aa}$ & \\
\hline \multirow{2}{*}{$\begin{array}{l}\text { Protein } \\
(\%)\end{array}$} & Fixed & $2.91 \mathrm{Ac}$ & $3.22 \mathrm{Ab}$ & $3.41 \mathrm{Aa}$ & \multirow{2}{*}{0.1175} \\
\hline & Variable & $3.12 \mathrm{Ac}$ & $3.40 \mathrm{Ab}$ & $3.58 \mathrm{Aa}$ & \\
\hline \multirow{2}{*}{$\begin{array}{l}\text { Lactose } \\
(\%)\end{array}$} & Fixed & 4.48Aab & $4.55 \mathrm{Aa}$ & $4.42 \mathrm{Ab}$ & \multirow{2}{*}{0.0541} \\
\hline & Variable & 4.40Aab & $4.45 \mathrm{Aa}$ & $4.30 \mathrm{Ab}$ & \\
\hline \multirow{2}{*}{$\begin{array}{l}\text { Total solids } \\
\text { (\%) }\end{array}$} & Fixed & $12.02 \mathrm{Ab}$ & $12.37 \mathrm{Aab}$ & $12.60 \mathrm{Aa}$ & \multirow{2}{*}{0.2640} \\
\hline & Variable & $11.91 \mathrm{Ac}$ & $12.62 \mathrm{Ab}$ & $13.13 \mathrm{Aa}$ & \\
\hline \multirow{2}{*}{$\begin{array}{l}\text { Nitrogen urea } \\
\left(\mathrm{mg} \mathrm{dL}^{-1}\right)\end{array}$} & Fixed & $14.29 \mathrm{Bc}$ & $16.55 \mathrm{Ab}$ & $18.70 \mathrm{Ba}$ & \multirow{2}{*}{0.6965} \\
\hline & Variable & $16.38 \mathrm{Ab}$ & $17.26 \mathrm{Ab}$ & $22.01 \mathrm{Aa}$ & \\
\hline \multirow{3}{*}{$\operatorname{Milk}^{(2)}$} & & ilk producti & onents $(\mathrm{kg}$ & er day) & \\
\hline & Fixed & $15.39 \mathrm{Aa}$ & $13.75 \mathrm{Ab}$ & $14.19 \mathrm{Ab}$ & \multirow{2}{*}{0.5203} \\
\hline & Variable & $16.38 \mathrm{Aa}$ & $14.25 \mathrm{Ab}$ & $12.81 \mathrm{Ac}$ & \\
\hline \multirow{2}{*}{ Fat } & Fixed & $0.585 \mathrm{Aa}$ & $0.513 \mathrm{Aa}$ & $0.542 \mathrm{Aa}$ & \multirow{2}{*}{0.0254} \\
\hline & Variable & $0.576 \mathrm{Aa}$ & $0.567 \mathrm{Aa}$ & $0.545 \mathrm{Aa}$ & \\
\hline \multirow{2}{*}{ Protein } & Fixed & $0.448 \mathrm{Aa}$ & $0.441 \mathrm{Aa}$ & $0.482 \mathrm{Aa}$ & \multirow{2}{*}{0.0149} \\
\hline & Variable & $0.504 \mathrm{Aa}$ & $0.477 \mathrm{Aa}$ & $0.453 \mathrm{Aa}$ & \\
\hline \multirow{2}{*}{ Lactose $^{(2)}$} & Fixed & $0.691 \mathrm{Aa}$ & $0.626 \mathrm{Ab}$ & $0.627 \mathrm{Ab}$ & \multirow{2}{*}{0.0246} \\
\hline & Variable & $0.720 \mathrm{Aa}$ & $0.635 \mathrm{Ab}$ & $0.552 \mathrm{Bc}$ & \\
\hline \multirow{2}{*}{ Total solids $^{(2)}$} & Fixed & $1.851 \mathrm{Aa}$ & $1.692 \mathrm{Ab}$ & 1.780Aab & \multirow{2}{*}{0.0523} \\
\hline & Variable & $1.935 \mathrm{Aa}$ & $1.709 \mathrm{Aab}$ & $1.668 \mathrm{Ab}$ & \\
\hline
\end{tabular}

${ }^{(1)}$ Means followed by equal letters, uppercase in the columns and lowercase in the rows, do not differ at $5 \%$ probability by the LSMeans test. ${ }^{(2)}$ Treatment $\mathrm{x}$ grazing cycle interaction was significant at $5 \%$ probability. SEM, standard error of the mean. 
of concentrate in 'Marandu' pastures. However, this consumption may be justified by the higher in vitro DM digestibility (IVDMD) in the forage obtained in this treatment and grazing cycle, which reflected the higher CP and EE levels (Table 2). The consumption of $\mathrm{CP}, \mathrm{NDF}$, and EE from the pastures was higher in the treatment with a variable rest period than in the treatment with a fixed rest period, not only in the third but also in the first grazing cycle (Table 3). The consumption of EE from the pasture was higher than that estimated by Mourthé et al. (2012), which was $256 \mathrm{~g}$ per day for lactating Holstein x Gyr cows receiving $6 \mathrm{~kg}$ per day of concentrate in 'Marandu' pastures.

There was neither effect of treatment, nor of grazing cycle, nor of the interaction between them on the contents of EE, NDF, and lignin of the pasture. For the contents of CP and IVDMD of the pasture, there was effect of the treatments and grazing cycle, and of the interaction between them (Table 2). The values of IVDMD are considered close to the 60 and $65.8 \%$ reported by Porto et al. (2009) and Fukumoto et al. (2010), in 'Marandu' pastures managed in a rotational grazing system under intermittent stocking, with pasture rest periods of 30 days, whereas the CP levels were higher than the values of 9.4 and $10 \%$ obtained in these same two studies. The higher level of CP observed in the pasture under variable rest periods in the third cycle (Table 2) -, associated with the higher estimated DM intake from the pasture, culminated in the higher CP intake observed in this treatment and grazing cycle (Table 3 ).

There was no effect of the treatments; however, an effect was produced by the interaction Trt $\mathrm{x}$ GC on the production of milk which, in general, irrespective of the rest period, was reduced considering the first and third grazing cycles, mainly because of the advanced lactation stage of the cows (Table 4). The grazing cycle produced an effect on the components of the milk; however, there was neither Trt x GC interaction nor effect of the treatment. There was neither effect of the treatment, nor of the grazing cycle, nor of the Trt x GC interaction on the fat and protein yields (Table 4). For the production of lactose and total solids, an effect of the grazing cycle and of the Trt x GC interaction was observed, and these results, in general, may be considered reflections on the milk production of cows.
There was no effect of the treatment on the contents of $\alpha$-linolenic, palmitic, linoleic, oleic, and stearic FAs of the pasture (Table 2), which were generally similar to those reported by Mourthé et al. (2015), in pastures of 'Marandu' palisade grass. The highest consumption values of linoleic and $\alpha$-linolenic FAs, the main precursors for the synthesis of vaccenic acid in the rumen and, consequently, of rumenic acid in milk, were observed under variable rest periods in the third cycle, which suggests the highest intake of pasture DM observed in this condition (Table 3), as previously discussed.

There was no effect of the treatments on the concentrations of linoleic, stearic, oleic, palmitic, and $\alpha$-linolenic FAs in plasma (Table 5), despite the differences observed in the consumption of these FAs, mainly in the third grazing cycle (Table 3). There was also no effect of the treatments on the plasma concentrations of rumenic, vaccenic, and C20:5 $\omega-3$ eicosapentaenoic (EPA) acids. The Trt x GC interaction was observed only for $\alpha$-linolenic, palmitic, and stearic FAs (Table 5). The FAs encountered at the highest concentrations in plasma were identified in the following order: linoleic, stearic, oleic, palmitic, and $\alpha$-linolenic. The high levels of linoleic and $\alpha$-linolenic FA in plasma may be attributed to the partial escape of these FAs from the rumen, as a consequence of the competition between biohydrogenation and the rate of passage through this compartment, and the preferential intestinal absorption of these essential FAs. However, Palladino et al. (2010) argued that the FA profile of cow plasma does not reliably reflect the status of FA availability in the gut and subsequent absorption. Mohammed et al. (2009) reported concentrations of 26.4, 14.3, 12.0, 10.0, 8.7, 2.18, and

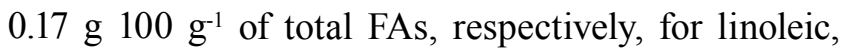
stearic, $\alpha$-linolenic, palmitic, oleic, vaccenic, and rumenic acids in the plasma of lactating Holstein cows, which received $3 \mathrm{~kg}$ per day of concentrate and grazed in temperate grasslands. Except for the lower concentrations of $\alpha$-linolenic and vaccenic acids, the other results obtained in the present study may be considered similar to those reported by Mohammed et al. (2009). It should be emphasized, however, that in the work of Mohammed et al. (2009), cows consumed more pasture (16.1 kg per cow per day) with a higher

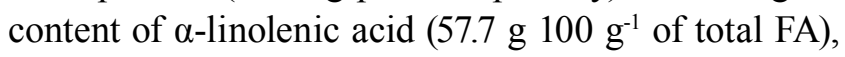


culminating in this FA consumption of $342 \mathrm{~g}$ per cow per day.

The effect of the Trt $\mathrm{x}$ GC interaction was observed in the FA concentrations of milk (Table 6). For the FA of milk for which there was no interaction, we elected to show only the results concerning the treatments (Table 7). In general, there was no effect of the different treatments on FA concentrations in milk (Tables 6 and 7), except for docosapentaenoic acid (DPA; C22:6 $\omega-3$ ), whose content was higher in the milk of cows of the treatment with variable rest period (Table 7). In studies on temperate grasses, designed to evaluate the strategy impacts of pasture managements (that is, different pasture masses and

Table 5. Effect of rest period and grazing cycle on plasma fatty acid composition of Holstein x Gyr cows consuming Urochloa brizantha 'Marandu' pasture ${ }^{(1)}$.

\begin{tabular}{|c|c|c|c|c|c|}
\hline \multirow{2}{*}{$\begin{array}{l}\text { Fatty acid } \\
\left({\left.\mathrm{g} 100 \mathrm{~g}^{-1}\right)}^{2}\right.\end{array}$} & \multirow[t]{2}{*}{ Rest period } & \multicolumn{3}{|c|}{ Grazing cycle } & \multirow[t]{2}{*}{ SEM } \\
\hline & & 1 & 2 & 3 & \\
\hline \multirow{2}{*}{$\mathrm{C} 16: 0^{(2)}$} & Fixed & $9.654 \mathrm{Aa}$ & $9.221 \mathrm{Ab}$ & $9.033 \mathrm{Ab}$ & \multirow{2}{*}{0.1398} \\
\hline & Variable & $9.008 \mathrm{Ab}$ & $9.546 \mathrm{Aa}$ & $9.385 \mathrm{Aa}$ & \\
\hline \multirow{2}{*}{$\mathrm{C} 18: 0^{(2)}$} & Fixed & 15.312Aab & $15.028 \mathrm{Ab}$ & $15.608 \mathrm{Aa}$ & \multirow{2}{*}{0.3954} \\
\hline & Variable & 14.319Ac & $15.263 \mathrm{Ab}$ & $15.741 \mathrm{Aa}$ & \\
\hline \multirow{2}{*}{ trans-11 C18:1 } & Fixed & $0.677 \mathrm{Ab}$ & $0.650 \mathrm{Ab}$ & $0.771 \mathrm{Aa}$ & \multirow{2}{*}{0.0428} \\
\hline & Variable & $0.606 \mathrm{Ab}$ & $0.609 \mathrm{Ab}$ & $0.728 \mathrm{Aa}$ & \\
\hline \multirow{2}{*}{ cis-9 C18:1 } & Fixed & $11.036 \mathrm{Aa}$ & $10.764 \mathrm{Aa}$ & 10.449Aa & \multirow{2}{*}{0.3692} \\
\hline & Variable & $10.630 \mathrm{Aa}$ & $11.333 \mathrm{Aa}$ & $10.802 \mathrm{Aa}$ & \\
\hline \multirow{2}{*}{ cis- 9, cis-12 C18:2 } & Fixed & $22.041 \mathrm{Aa}$ & $21.682 \mathrm{Aa}$ & $20.396 \mathrm{Ab}$ & \multirow{2}{*}{0.6333} \\
\hline & Variable & $22.082 \mathrm{Aa}$ & $21.730 \mathrm{Aa}$ & $20.592 \mathrm{Ab}$ & \\
\hline \multirow{2}{*}{ cis- 9, cis-12, cis-15 C18:3(2) } & Fixed & $5.326 \mathrm{Ab}$ & $5.181 \mathrm{Ab}$ & $5.842 \mathrm{Aa}$ & \multirow{2}{*}{0.2969} \\
\hline & Variable & $5.808 \mathrm{Aa}$ & $5.033 \mathrm{Ab}$ & $5.652 \mathrm{Aa}$ & \\
\hline \multirow{2}{*}{ cis-9, trans-11 CLA } & Fixed & 0.119Aa & $0.112 \mathrm{Ab}$ & 0.119Aa & \multirow{2}{*}{0.0083} \\
\hline & Variable & $0.127 \mathrm{Aa}$ & $0.104 \mathrm{Ab}$ & $0.121 \mathrm{Aa}$ & \\
\hline \multirow{2}{*}{ C20:5 $\omega-3$ Eicosapentaenoic acid (EPA) } & Fixed & $0.916 \mathrm{Ab}$ & $0.982 \mathrm{Ab}$ & $1.049 \mathrm{Aa}$ & \multirow{2}{*}{0.0432} \\
\hline & Variable & $0.984 \mathrm{Ab}$ & $1.047 \mathrm{Ab}$ & $1.125 \mathrm{Aa}$ & \\
\hline
\end{tabular}

${ }^{(1)}$ Means followed by equal letters, uppercase in the columns and lowercase in the rows, do not differ at $5 \%$ probability by the LSMeans test. ${ }^{(2)}$ Treatment $\mathrm{x}$ grazing cycle interaction was significant at 5\% probability. SEM, standard error of the mean.

Table 6. Effect of the rest period and grazing cycle on milk fatty acid composition from Holstein x Gyr cows consuming Urochloa brizantha 'Marandu' pasture ${ }^{(1)}$.

\begin{tabular}{|c|c|c|c|c|c|}
\hline \multirow{2}{*}{$\begin{array}{l}\text { Fatty acid } \\
\left(\mathrm{g} 100 \mathrm{~g}^{-1}\right)^{(2)}\end{array}$} & \multirow[t]{2}{*}{ Rest period } & \multicolumn{3}{|c|}{ Grazing cycle } & \multirow[t]{2}{*}{ SEM } \\
\hline & & 1 & 2 & 3 & \\
\hline \multirow{2}{*}{$\Sigma$ short-chain FA $(\mathrm{C} 4: 0+\mathrm{C} 6: 0+\mathrm{C} 8: 0+\mathrm{C} 10: 0)$} & Fixed & $9.596 \mathrm{Aa}$ & $9.638 \mathrm{Aa}$ & $9.672 \mathrm{Aa}$ & \multirow{2}{*}{0.2875} \\
\hline & Variable & $10.115 \mathrm{Aa}$ & $9.700 \mathrm{Ab}$ & $9.508 \mathrm{Ab}$ & \\
\hline \multirow{2}{*}{ C12:0 } & Fixed & $3.025 \mathrm{Aa}$ & $3.082 \mathrm{Aa}$ & $2.986 \mathrm{Aa}$ & \multirow{2}{*}{0.1195} \\
\hline & Variable & $3.269 \mathrm{Aa}$ & $3.205 \mathrm{Aa}$ & $2.932 \mathrm{Ab}$ & \\
\hline \multirow{2}{*}{ C14:0 } & Fixed & $10.759 \mathrm{Aa}$ & $11.132 \mathrm{Aa}$ & $10.599 \mathrm{Ab}$ & \multirow{2}{*}{0.2295} \\
\hline & Variable & $11.104 \mathrm{Aa}$ & $11.199 \mathrm{Aa}$ & $10.383 \mathrm{Ab}$ & \\
\hline \multirow{2}{*}{$\mathrm{C} 18: 0$} & Fixed & $10.793 \mathrm{Aa}$ & $9.405 \mathrm{Ac}$ & $9.937 \mathrm{Ab}$ & \multirow{2}{*}{0.3483} \\
\hline & Variable & $10.567 \mathrm{Aa}$ & $9.772 \mathrm{Ab}$ & $11.078 \mathrm{Aa}$ & \\
\hline \multirow{2}{*}{ trans-10 C18:1 } & Fixed & $0.194 \mathrm{Ab}$ & $0.152 \mathrm{Ac}$ & $0.218 \mathrm{Aa}$ & \multirow{2}{*}{0.0090} \\
\hline & Variable & $0.175 \mathrm{Ab}$ & $0.142 \mathrm{Ac}$ & $0.242 \mathrm{Aa}$ & \\
\hline \multirow{2}{*}{ cis -9, cis -12, cis -15 C18:3 $(\omega-3)$} & Fixed & $0.400 \mathrm{Ab}$ & $0.407 \mathrm{Ab}$ & $0.431 \mathrm{Aa}$ & \multirow{2}{*}{0.0140} \\
\hline & Variable & $0.400 \mathrm{Aab}$ & $0.385 \mathrm{Ab}$ & $0.421 \mathrm{Aa}$ & \\
\hline \multirow{2}{*}{ cis -9, trans-11 CLA } & Fixed & $0.756 \mathrm{Ab}$ & $0.791 \mathrm{Ab}$ & $0.927 \mathrm{Aa}$ & \multirow{2}{*}{0.0449} \\
\hline & Variable & $0.763 \mathrm{Ab}$ & $0.711 \mathrm{Ac}$ & $0.877 \mathrm{Aa}$ & \\
\hline
\end{tabular}

${ }^{(1)}$ Means followed by equal letters, uppercase in the columns and lowercase in the rows, do not differ at 5\% probability by the LSMeans test. ${ }^{(2)}$ Treatment $\mathrm{x}$ grazing cycle interaction was significant at 5\% probability. SEM, standard error of the mean. 
pasture supplies) on the FA profile of milk, effects were observed on the concentrations of lauric, oleic, linoleic (Bargo et al., 2006), myristic, pentadecylic (C15:0), and $\alpha$-linolenic FAs (Palladino et al., 2009), as well as myristic, palmitic, vaccenic, and $\alpha$-linolenic FAs (Palladino et al., 2014). The reported results in these three studies, corroborated by the present work, show the difficulty of promoting changes in the FA profile of milk by pasture management strategies, even when differences are observed in the consumption of linoleic and $\alpha$-linolenic FAs, as observed in the present study and by Palladino et al. (2009, 2014).

The differences observed between treatments occurred mainly in the third cycle, in the consumption of linoleic and $\alpha$-linolenic acids (Table 3), which, together with oleic acid, are the primary substrates for the formation of vaccenic acid in the rumen (Shingfield et al., 2010). These differences did not promote substantial alterations in the normal routes of ruminal biohydrogenation of FAs. The common end product of these routes is stearic acid, for which the primary intermediates found are the trans 6 to trans-16 C18:1, cis-10 to cis-15 C18:1 FAs, in addition to conjugated isomers (for instance, rumenic acid, trans-9, cis-11 CLA, and trans-10, cis-12 CLA) and nonconjugated isomers of linoleic acid (Shingfield et al., 2010; Buccioni et al., 2012). The concentrations of stearic acid, observed in cow's milk in the present study (Table 6), may be considered normal, as the concentrations are within the range of levels compiled by Lopes et al. (2015) from 15 studies on cows, in tropical grass pastures not supplemented with lipid

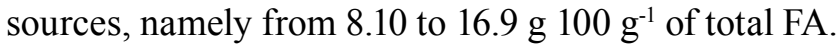
Additionally, the similarity in the total concentrations of branched-chain FAs (iso and anteiso) and linear odd-chain FAs (OCFA) in milk (Table 7), which originated mainly from FAs synthesized de novo and are incorporated into the cellular membrane of rumen bacteria (Vlaeminck et al., 2006), may indicate that the ruminal environment of cows managed under fixed and variable grazing was similar between treatments, and favourable to fibrolytic microbiota for fermentation of fibrous carbohydrates from pasture and to the acetate production. Acetate is the principal precursor of the de novo synthesis of C4:0, C6:0, C8:0, C10:0, C12:0, C14:0, and C16:0 FAs in the mammary gland (Shingfield et al., 2010), hence, the similarity between treatments in the levels of these FAs (Tables 6 and 7). Among the trans $\mathrm{C} 18: 1$ isomers, intermediates to the ruminal biohydrogenation of linoleic and $\alpha$-linolenic FAs (Shingfield et al., 2010) and of interest for human health, vaccenic, elaidic (trans-9 C18:1), and trans-10 C18:1 FAs can be highlighted. The latter two have been associated with deleterious effects on cardiovascular health (Almeida et al., 2014); for this reason, the reduction of their content in milk is desirable. However,

Table 7. Effect of the rest period on the milk fatty acid (FA) composition of Holstein x Gyr cows consuming Urochloa brizantha 'Marandu' pasture ${ }^{(1)}$.

\begin{tabular}{|c|c|c|c|c|}
\hline \multirow{2}{*}{$\begin{array}{l}\text { FA } \\
\left(\mathrm{g} 100 \mathrm{~g}^{-1}\right)\end{array}$} & \multicolumn{2}{|c|}{ Rest period } & \multirow[t]{2}{*}{ Standard error of the mean } & \multirow[t]{2}{*}{ p-value } \\
\hline & Fixed & Variable & & \\
\hline C16:0 & $29.564 \mathrm{a}$ & $28.896 \mathrm{a}$ & 0.7296 & 0.5283 \\
\hline trans-9 C16:1 & $0.080 \mathrm{a}$ & $0.073 \mathrm{a}$ & 0.0330 & 0.1479 \\
\hline trans $-9 \mathrm{C} 18: 1$ & $0.183 \mathrm{a}$ & $0.176 \mathrm{a}$ & 0.0028 & 0.0748 \\
\hline trans-11 C18:1 & $1.497 \mathrm{a}$ & $1.444 \mathrm{a}$ & 0.0540 & 0.5035 \\
\hline$\sum$ trans $\mathrm{C} 18: 1 \mathrm{FA}^{(2)}$ & $2.824 \mathrm{a}$ & $2.780 \mathrm{a}$ & 0.0659 & 0.6428 \\
\hline cis-9 C18:1 & $19.437 \mathrm{a}$ & $19.724 a$ & 0.4843 & 0.6818 \\
\hline cis-9, cis-12 C18:2 & $0.766 \mathrm{a}$ & $0.771 \mathrm{a}$ & 0.0301 & 0.9128 \\
\hline trans-10, cis-12 CLA & $0.009 \mathrm{a}$ & $0.009 \mathrm{a}$ & 0.0004 & 0.2297 \\
\hline trans-9, cis-11 CLA & $0.022 \mathrm{a}$ & $0.021 \mathrm{a}$ & 0.0010 & 0.8117 \\
\hline $\mathrm{C} 20: 5 \omega-3$ (EPA) & $0.038 \mathrm{a}$ & $0.039 \mathrm{a}$ & 0.0013 & 0.7561 \\
\hline $\mathrm{C} 22: 5 \omega-3$ (DPA) & $0.068 \mathrm{a}$ & $0.077 \mathrm{~b}$ & 0.0024 & 0.0289 \\
\hline$\sum \mathrm{OBCFA}^{(3)}$ & $4.277 \mathrm{a}$ & $4.265 \mathrm{a}$ & 0.0790 & 0.9132 \\
\hline$\Sigma$ cis $\omega-3$ FA & $0.519 \mathrm{a}$ & $0.518 \mathrm{a}$ & 0.0142 & 0.9392 \\
\hline$\underline{\Sigma c i s \omega-6 \mathrm{FA}}$ & $0.998 \mathrm{a}$ & $1.021 \mathrm{a}$ & 0.0355 & 0.6524 \\
\hline
\end{tabular}

${ }^{(1)}$ Means followed by equal letters do not differ at $5 \%$ probability by the LSMeans test. ${ }^{(2)} \Sigma$ trans $\mathrm{C} 18: 1 \mathrm{FA}=$ trans $-4 \mathrm{C} 18: 1+$ trans $-5 \mathrm{C} 18: 1+$ trans $6-8$ $\mathrm{C} 18: 1+$ trans-9 C18:1 + trans-10 C18:1 + trans-11 C18:1 + trans-12 C18:1 + trans-13 and trans-14 C18:1 + trans-16 C18:1. ${ }^{(3)} \Sigma$ OBCFA (odd and branchedchain fatty acids $)=\Sigma$ anteiso FA + iso FA $+(\mathrm{C} 5: 0+\mathrm{C} 7: 0+\mathrm{C} 9: 0+\mathrm{C} 11: 0+\mathrm{C} 15: 0+\mathrm{C} 17: 0+$ cis-9 C17:1 + C21:0 + C23:0). 
vaccenic acid, which is the major isomer among all of the trans C18:1 isomers, is responsible for 64 to $97 \%$ of the total amount of rumenic acid secreted into bovine milk, via the enzyme stearoyl-CoA desaturase in the mammary gland (Shingfield et al., 2008); therefore, an increase in its content in milk should be desirable. In addition, vaccenic acid is a precursor for $19 \%$ of the synthesis of rumenic acid in human tissues (Turpeinen et al., 2002). The regression of the contents of rumenic (y) vs. vaccenic (x) acid shows the close association between these two FAs $(\hat{y}=0.19562+0.41382 x$; $\mathrm{r}^{2}=0.47, \mathrm{p}<0.0001$ ), also reported by Bargo et al. (2006) and Mourthé et al. (2015). The concentrations of rumenic acid in milk (Table 6) are within the concentrations compiled by Lopes et al. (2015) in 15 studies with cows in tropical grass pastures, without lipid source supplementation. However, the concentrations are higher than the normally observed

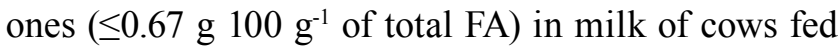
corn silage supplemented with concentrates void of ingredients rich in $\alpha$-linolenic and linoleic FAs (Lopes et al., 2011b), which shows the greater nutraceutical potential of milk produced in pastures.

The trans-9, cis-11 CLA and trans-10, cis-12 CLA are generated in the rumen from partial biohydrogenation reactions of linoleic acid (Buccioni et al., 2012), and the increase of their concentrations in bovine milk is associated with a decrease of fat content (Shingfield et al., 2010). However, in the present study, the observed concentrations of these FAs in milk (Table 7) were not sufficient to promote any decreases of fat content.

Oleic acid was the FA with the second highest concentration in milk, which corroborates the literature (Lopes et al., 2015). The contents of oleic acid observed (Table 7) are within the range of 16.6

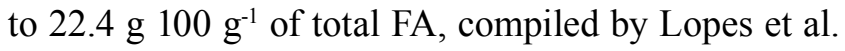
(2015) from three studies with cows in $U$. brizantha pastures, without supplementation with lipid sources.

Lopes et al. (2011a) and Mourthé et al. (2012) reported concentrations of linoleic and $\alpha$-linolenic acids varying, respectively, from 1.16 to 1.76 and from

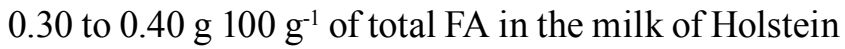
x Gyr cows, in pastures of U. brizantha without lipid source supplementation. In the present study, the contents of linoleic acid (Table 7) were lower than the reported ones by these authors, whereas the contents of $\alpha$-linolenic acid (Table 6) can be considered similar. Therefore, it can be inferred that there was a significant transfer of $\alpha$-linolenic acid from plasma to milk, whereas for linoleic acid, this transfer was not observed. Nevertheless, as concluded by Palladino et al. (2010), the FA profile of milk may not accurately reflect the profile observed in plasma.

There was no effect $(p>0.05)$ of the different treatments on the concentrations of lauric, myristic, stearic (Table 6), palmitic, and oleic FAs, or on the sum of the contents of the $\omega-6$ and $\omega-3$ FAs (Table 7). This was reflected in the similarity in the nutritional quality of milk fat, measured by AI, TI, and by the $\omega-6: \omega-3$ ratio, and the $\mathrm{h} / \mathrm{H}$ ratio. For the first three indices, there was no effect caused by the treatments, grazing cycles, or the Trt x GC interactions, and the main values obtained were $3.67,4.14$, and 0.463 , respectively, for the treatment with a fixed rest period, and 3.59, 4.07, and 0.475 for the variable rest period. For the $\mathrm{h} / \mathrm{H}$ ratio, there was an effect, caused by the grazing cycle and the Trt x GC interaction, with the range of values observed for the fixed and variable rest periods of 1.79 to 2.08 and 1.87 to 2.05 , respectively.

\section{Conclusion}

The pasture management of Urochloa brizantha 'Marandu' with 30 days of rest or $95 \%$ light interception does not alter the fatty acid profile of milk from Holstein x Gyr cows.

\section{Acknowledgments}

To Embrapa (SEG 03.10.06.033.00) and to Fundação de Amparo à Pesquisa do Estado de Minas Gerais (Fapemig, PPM 00311-12), for financial support; to Conselho Nacional de Desenvolvimento Científico e Tecnológico (CNPq, process No. 503811/2010-6 and 140799/2011-7), for student scholarships; and to the technicians Ernando Ferreira Motta and Hernani Guilherme Barbosa Filho, who performed the analyses of fatty acid composition at the laboratory of chromatography of Embrapa Gado de Leite.

\section{References}

ALMEIDA, M.M. de; LUQUETTI, S.C.D.; SABARENSE, C.M.; CORRÊA, J.O. do A.; REIS, L.G. dos; CONCEIÇÃO, E.P.S. da; LISBOA, P.C.; MOURA, E.G. de; GAMEIRO, J.; GAMA, M.A.S. da; LOPES, F.C.F.; GONZÁLEZ GARCIA, R.M. Butter naturally enriched in cis-9 trans-11 CLA prevents hyperinsulinemia and increases both serum HDL cholesterol and triacylglycerol levels 
in rats. Lipids in Health and Disease, v.13, p.1-13, 2014. DOI: 10.1186/1476-511X-13-200.

ANJOS, A.J. dos; GOMIDE, C.A. de M.; RIBEIRO, K.G.; MADEIRO, A.S.; MORENZ, M.J.F.; PACUILLO, D.S.C. Forage mass and morphological composition of Marandu palisade grass pasture under rest periods. Ciência e Agrotecnologia, v.40, p.7686, 2016. DOI: 10.1590/S1413-70542016000100007.

BARGO, F.; DELAHOY, J.E.; SCHROEDER, G.F.; MULLER, L.D. Milk fatty acid composition of dairy cows grazing at two pasture allowances and supplemented with different levels and sources of concentrate. Animal Feed Science and Technology, v.125, p.17-31, 2006. DOI: 10.1016/j.anifeedsci.2005.05.010.

BUCCIONI, A.; DECANDIA, M.; MINIERI, S.; MOLLEB, G.; CABIDDUB, A. Lipid metabolism in the rumen: new insights on lipolysis and biohydrogenation with an emphasis on the role of endogenous plant factors. Animal Feed Science and Technology, v.174, p.1-25, 2012. DOI: 10.1016/j.anifeedsci.2012.02.009.

CUNNINGHAM, J.G. Tratado de fisiologia veterinária. 3.ed. Rio de Janeiro: Guanabara Koogan, 2004. 577p.

FATS and fatty acids in human nutrition. Roma: FAO, 2010. 166p. Report of an expert consultation.

FUKUMOTO, N.M.; DAMASCENO, J.C.; DERESZ, F.; MARTINS, C.E.; CÓSER, A.C.; SANTOS, G.T. dos. Produção e composição do leite, consumo de matéria seca e taxa de lotação em pastagens de gramíneas tropicais manejadas sob lotação rotacionada. Revista Brasileira de Zootecnia, v.39, p.1548-1557, 2010. DOI: 10.1590/S1516-35982010000700022.

LOPES, F.C.F.; BARROS, P.A.V.; BRUSCHI, J.H.; SILVA, P.H.F.; PEIXOTO, M.G.C.D.; GOMIDE, C.A.M.; DUQUE, A.C.A.; GAMA, M.A.S. Perfil de ácidos graxos no leite de vacas Holandês em pastagens tropicais suplementadas com dois níveis de concentrado. Arquivo Brasileiro de Medicina Veterinária e Zootecnia, v.63, p.518-521, 2011a. DOI: 10.1590/S010209352011000200037.

LOPES, F.C.F.; GAMA, M.A.S. da; RIBEIRO, C.G.S.; MOURTHÉ, M.H.F.; BARROS, P.A.V. de; SOUZA, S.M. de. Produção de leite com alto teor de CLA: experiência brasileira. In: PEREIRA, L.G.R.; NOBRE, M.M.; NEVES, A.L.A.; CAMPOS, M.M.; MENDONÇA, L.C.; GOMIDE, C.A. de M.; SANTOS, G.C. dos; SIQUEIRA, K.B. da. (Ed.). Pesquisa, desenvolvimento e inovação para sustentabilidade da bovinocultura leiteira. Juiz de Fora: Embrapa Gado de Leite, 2011b. p.251-296.

LOPES, F.C.F.; SILVA, B.C. da M. e; ALMEIDA, M.M. de; GAMA, M.A.S. da. Lácteos naturalmente enriquecidos com ácidos graxos benéficos à saúde. In: MARTINS, P. do C.; PICCININI, G.A.; KRUG, E.E.B.; MARTINS, C.E.; LOPES, F.C.F. Sustentabilidade ambiental, social e econômica da cadeia produtiva do leite: desafios e perspectivas. Brasília: Embrapa, 2015. p.237-309.

MACEDO, M.C.M. Aspectos edáficos relacionados com a produção de Brachiaria brizantha cultivar Marandu. In: BARBOSA, R.A. (Ed.). Morte de pastos de braquiárias. Campo Grande: Embrapa Gado de Corte, 2006. p.35-65.

MADEIRO, A.S. Consumo de pasto, produção e composição do leite de vacas em pastagem de capim-marandu manejado sob lotação intermitente. 2014. 62p. Tese (Doutorado) - Universidade Federal Rural do Rio de Janeiro, Seropédica.

MASOOD, A.; STARK, K.D.; SALEM JR, N. A simplified and efficient method for the analysis of fatty acid methyl esters suitable for large clinical studies. Journal of Lipid Research, v.46, p.2299-2305, 2005. DOI: 10.1194/jlr.D500022-JLR200.

MOHAMMED, R.; STANTON, C.S.; KENNELLY, J.J.; KRAMER, J.K.G.; MEE, J.F.; GLIMM, D.R.; O'DONOVAN, M.; MURPHY, J.J. Grazing cows are more efficient than zero-grazed and grass silage-fed cows in milk rumenic acid production. Journal of Dairy Science, v.92, p.3874-3893, 2009. DOI: 10.3168/ jds.2008-1613.

MOURTHÉ, M.H.F.; REIS, R.B.; GAMA, M.A.S.; BARROS, P.A.V.; ANTONIASSI, R.; BIZZO, H.R.; LOPES, F.C.F. Perfil de ácidos graxos do leite de vacas Holandês x Gir em pastagem de capim-marandu suplementado com quantidades crescentes de grão de soja tostado. Arquivo Brasileiro de Medicina Veterinária e Zootecnia, v.67, p.1150-1158, 2015. DOI: 10.1590/1678-4162-7489.

MOURTHÉ, M.H.F.; REIS, R.B.; LOPES, F.C.F.; GAMA, M.A.S.; SOUZA, R.C. Desempenho, composição do leite e metabólitos sanguíneos de vacas Holandês x Gir manejadas em pastagem de Brachiaria brizantha cv. Marandu e suplementadas com grão de soja tostado. Arquivo Brasileiro de Medicina Veterinária e Zootecnia, v.64, p.1223-1231, 2012. DOI: 10.1590/ S0102-09352012000500021.

PALLADINO, R.A.; BUCKLEY, F.; PRENDIVILlE, R.; MURPHY, J.J.; CALLAN, J.; KENNY, D.A. A comparison between Holstein-Friesian and Jersey dairy cows and their $F_{1}$ hybrid on milk fatty acid composition under grazing conditions. Journal of Dairy Science, v.93, p.2176-2184, 2010. DOI: 10.3168/ jds.2009-2453.

PALLADINO, R.A.; O'DONOVAN, M.; KENNY, D.A. Fatty acid intake and rumen fatty acid composition is affected by pregrazing herbage mass and daily herbage allowance in Holstein dairy cows. Spanish Journal of Agricultural Research, v.12, p.708-716, 2014. DOI: 10.5424/sjar/2014123-5578.

PALLADINO, R.A.; O’DONOVAN, M.; MURPHY, J.J.; MCEVOY, M.; CALLAN, J.; BOLAND, T.M.; KENNY, D.A. Fatty acid intake and milk fatty acid composition of Holstein dairy cows under different grazing strategies: herbage mass and daily herbage allowance. Journal of Dairy Science, v.92, p.52125223, 2009. DOI: 10.3168/jds.2009-2404.

PORTO, P.P.; DERESZ, F.; SANTOS, G.T. dos; LOPES, F.C.F.; CECATO, U.; CÓSER A.C. Produção e composição química do leite, consumo e digestibilidade de forragens tropicais manejadas em sistema de lotação intermitente. Revista Brasileira de Zootecnia, v.38, p.1422-1431, 2009. DOI: 10.1590/S151635982009000800005 .

RAJALA-SCHULTZ, P.J.; SAVILLE, W.J.A. Sources of variation in milk urea nitrogen in Ohio dairy herds. Journal of Dairy Science, v.86, p.1653-1661, 2003. DOI: 10.3168/jds.S00220302(03)73751-5.

RIBEIRO, C.G.S.; LOPES, F.C.F.; GAMA, M.A.S.; MORENZ, M.J.F.; RODRIGUEZ, N.M. Desempenho produtivo e perfil de ácidos graxos do leite de vacas que receberam níveis crescentes 
de óleo de girassol em dietas à base de capim-elefante. Arquivo Brasileiro de Medicina Veterinária e Zootecnia, v.66, p.15131521, 2014. DOI: 10.1590/1678-6886.

ROSELER, D.K.; FERGUSON, J.D.; SNIFFEN, C.J.; HERREMA, J. Dietary protein degradability effects on plasma and milk urea nitrogen and milk nonprotein nitrogen in Holstein cows. Journal of Dairy Science, v.76, p.525-534, 1993. DOI: 10.3168/jds.S00220302(93)77372-5.

SHINGFIELD, K.J.; BERNARD, L.; LEROUX, C.; CHILLIARD, Y. Role of trans fatty acids in the nutritional regulation of mamary lipogenesis in ruminants. Animal, v.4, p.1140-1166, 2010. DOI: 10.1017/S1751731110000510.

SHINGFIELD, K.J.; CHILlIARD, Y.; TOIVONEN, V.; KAIRENIUS, P.; GIVENS, D.I. Trans fatty acids and bioactive lipids in ruminant milk. In: BÕSZE, Z. (Ed.). Bioactive components of milk. New York: Springer, 2008. p.3-65. (Advances in experimental medicine and biology, 606). DOI: 10.1007/978-0-387-74087-4_1.
SILVA, J.S.; QUEIROZ, A.C. de. Análise de alimentos: métodos químicos e biológicos. 3.ed. Viçosa: Universidade Federal de Viçosa, 2002. 235p.

SILVA, M.V.G.B. da; CANAZO-CAYO, A.W.; LOPES, P.S.; COBUCI, J.A.; MARTINS, M.F.; PAIVA, L. de C.; CEMBRANELLI, M. de A.R.; FERREIRA, M.B.D.; PANETTO, J.C. do C. Programa de melhoramento genético da raça Girolando: do teste de progênie às avaliações genômicas. Informe Agropecuário, v.36, p.35-40, 2015.

TURPEINEN, A.M.; MUTANEN, M; ARO, A.; SALMINEN, I.; BASU, S.; PALMQUIST, D.L.; GRIINARI, J.M. Bioconversion of vaccenic acid to conjugated linoleic acid in humans. The American Journal of Clinical Nutrition, v.76, p.504-510, 2002.

VLAEMINCK, B.; FIEVEZ, V.; DEMEYER, D.; DEWHURST, R.J. Effect of forage: concentrate ratio on fatty acid composition of rumen bacteria isolated from ruminal and duodenal digesta. Journal of Dairy Science, v.89, p.2668-2678, 2006. DOI: 10.3168/ jds.S0022-0302(06)72343-8

Received on June 28, 2016 and accepted on November 23, 2016 